\title{
Extreme events in gross primary production: a characterization across continents
}

\author{
J. Zscheischler ${ }^{1,2,3}$, M. Reichstein ${ }^{1}$, S. Harmeling ${ }^{2}$, A. Rammig ${ }^{4}$, E. Tomelleri ${ }^{1, *}$, and M. D. Mahecha ${ }^{1}$ \\ ${ }^{1}$ Max Planck Institute for Biogeochemistry, Jena, Germany \\ ${ }^{2}$ Max Planck Institute for Intelligent Systems, Tübingen, Germany \\ ${ }^{3}$ Institute for Atmospheric and Climate Science, ETH Zürich, Switzerland \\ ${ }^{4}$ Potsdam Institute for Climate Impact Research, Potsdam, Germany \\ *now at: EURAC, Institute for Applied Remote Sensing, Bozen, Italy
}

Correspondence to: J. Zscheischler (jzsch@bgc-jena.mpg.de)

Received: 19 December 2013 - Published in Biogeosciences Discuss.: 31 January 2014

Revised: 7 April 2014 - Accepted: 10 April 2014 - Published: 4 June 2014

\begin{abstract}
Climate extremes can affect the functioning of terrestrial ecosystems, for instance via a reduction of the photosynthetic capacity or alterations of respiratory processes. Yet the dominant regional and seasonal effects of hydrometeorological extremes are still not well documented and in the focus of this paper. Specifically, we quantify and characterize the role of large spatiotemporal extreme events in gross primary production (GPP) as triggers of continental anomalies. We also investigate seasonal dynamics of extreme impacts on continental GPP anomalies. We find that the 50 largest positive extremes (i.e., statistically unusual increases in carbon uptake rates) and negative extremes (i.e., statistically unusual decreases in carbon uptake rates) on each continent can explain most of the continental variation in GPP, which is in line with previous results obtained at the global scale. We show that negative extremes are larger than positive ones and demonstrate that this asymmetry is particularly strong in South America and Europe. Our analysis indicates that the overall impacts and the spatial extents of GPP extremes are power-law distributed with exponents that vary little across continents. Moreover, we show that on all continents and for all data sets the spatial extents play a more important role for the overall impact of GPP extremes compared to the durations or maximal GPP. An analysis of possible causes across continents indicates that most negative extremes in GPP can be attributed clearly to water scarcity, whereas extreme temperatures play a secondary role. However, for Europe, South
\end{abstract}

America and Oceania we also identify fire as an important driver. Our findings are consistent with remote sensing products. An independent validation against a literature survey on specific extreme events supports our results to a large extent.

\section{Introduction}

The terrestrial carbon cycle is tightly linked to the global climate system. Favorable conditions for vegetation in the future are expected to increase terrestrial carbon uptake, while extreme climatic conditions might drastically decrease this uptake (Reichstein et al., 2013). Separating the enhancing and attenuating effects of growth in the terrestrial biosphere requires, besides others, a precise understanding of the feedbacks between climate extremes and terrestrial carbon fluxes.

The impacts of climate extremes on ecosystems and the carbon cycle are diverse. Storms transform carbon stocks from living biomass to dead wood and thus increase the risk of fire and pathogen outbreaks (Negrón-Juárez and Chambers, 2010). Droughts and heat waves have an impact on plant physiology, phenology and carbon allocation (Ciais et al., 2005; Reichstein et al., 2007; Phillips et al., 2009). Inevitable consequences are often increased tree mortality, higher fire risks and susceptibility to pathogens. In the long term, droughts might also influence vegetation composition. In general, impacts of droughts on the carbon cycle are 
difficult to assess, which is partly due to lagged effects like increased tree mortality in years after a severe drought (Bréda et al., 2006; Bigler et al., 2007), or changes in the respiration of soil heterotrophic organisms a year after an anomalously warm season (Arnone et al., 2008). Fires have an immediate and large impact on carbon stocks and vegetation structure (Westerling et al., 2006; Field et al., 2009). Ice storms and frost may cause physical damage up to whole-stand destruction (Irland, 2000; Sun et al., 2012). Hence, it is a major challenge to design an analytic approach that consistently quantifies the diverse impacts of climate extremes on the terrestrial biosphere.

The classical approach to investigate the effects of climate extremes on the carbon cycle is based on a "forward" analysis: The analyst identifies extreme events in climate variables or other environmental drivers and subsequently analyzes the impacts on ecosystems and the carbon cycle (examples can be found in Page et al., 2002; Ciais et al., 2005; Kurz et al., 2008; Zeng et al., 2009; Zhao and Running, 2010). This forward approach is appealing because one can emphasize a certain region or specific time span or concentrate on a single extreme event to study the consequences for ecosystem functioning. However, one has to be prepared to acknowledge that climate extremes do not necessarily translate into extreme responses of the biosphere. Inversely, not all extreme responses of the terrestrial biosphere are unambiguously explicable by some climate extreme or disturbance event. For instance, a very unlikely constellation of drivers, none of which are extreme in their own domain, might still cause extreme changes in ecosystems (so-called compound extremes, IPCC, 2012; Leonard et al., 2013). To tackle this aspect, Smith (2011) suggested the definition of an extreme climatic event (ECE) as "an episode or occurrence in which a statistically rare or unusual climatic period alters ecosystem structure and/or function". A pure forward analysis, instead, is at risk of overlooking extreme changes in the state of the biosphere and hence is not always desirable. An event-based analysis of the sort described above can potentially also lead to a biased perception of extreme events. Extreme events that affect regions of social or economical interest gain more attention than extreme events in regions with less public interest. For instance, very few experimental studies are done in Africa. In contrast, in a global analysis of extreme events the attention is distributed more equally.

In a recent study, Zscheischler et al. (2014) presented a quantification of negative extremes in gross primary production (GPP) based on four different data sets at the global scale. This study explicitly adopted an impact-driven perspective aiming for an assessment of globally relevant extreme changes in an impact variable (see also Reichstein et al., 2013). We define the impact variable as a variable describing the state of the biosphere, including the fraction of absorbed photosynthetically active radiation (fAPAR), leaf area index (LAI), the enhanced vegetation index (EVI), or biosphere-atmosphere carbon exchange.
At a glance, an obvious approach to identify extremes in time series would be based on the extreme value theory (EVT, Coles, 2001; Ghil et al., 2011), where samples exceeding a specific threshold are modeled using an appropriate extreme value distribution. This approach is called peak over threshold method (POT). Gumbel (2004) showed that for any well-behaved initial distribution only a few models are needed. However, because the sample size is limited by the samples exceeding the set threshold, this approach is not feasible for analyses based on satellite remote sensing observations (or derived products), where we typically deal with comparatively short time series. Another important aspect to consider is that we are generally interested in extremes affecting large contiguous areas and/or long time periods. More formally, we are interested in the "volume of extreme events", which we define as three-dimensional structures contiguous in time and space, where each single value exceeds a certain threshold. For that reason, here we use an alternative approach motivated by a three-dimensional drought assessment (Lloyd-Hughes, 2012; Zscheischler et al., 2013).

In this contribution, we directly follow up on Zscheischler et al. (2014) where it was shown that a few extreme events in GPP explain most of its global interannual variability. Here, we further investigate the regional and temporal characteristics of extreme events in GPP. In particular, we will look for regions in time and space where carbon uptake is much lower compared to normal conditions. We will then trace these extreme changes back to anomalous meteorological variables or fires and aim at understanding continental differences. It has been suggested earlier that the size distribution of extreme events in the biosphere follow a power law (Zscheischler et al., 2013, 2014; Reichstein et al., 2013). One question we address here is whether this power-law behavior is robust across continents and different spatial and temporal resolutions. To validate our approach we compare the spatial patterns of GPP extreme events with extremes in independent remote sensing products and the current literature.

\section{Material and methods}

\subsection{Data}

The study is based on four different data sets describing GPP covering the last 30 years (1982-2011). The range of the data sets spans from purely data-driven (upscaled model tree ensemble, MTE, Jung et al., 2011) over semiempirical (based on light-use efficiency, MOD17+, Running et al., 2004) towards process-based global ecosystem (LundPotsdam-Jena Dynamic Global Vegetation Model for managed Land, LPJmL, Bondeau et al., 2007) and land-surface models (OCN, Zaehle and Friend, 2010). 
MTE involves training a model tree ensemble at site level using FLUXNET (a global network of eddy covariance observations in tandem with site level meteorology; Baldocchi et al., 2001) to extrapolate to large spatiotemporal domains. We use a fully data-driven upscaling product that relies mainly on a composite of different remote sensing fAPAR products but also uses climate data from ERA interim (Dee et al., 2011).

MOD17+ is derived using the same model structure as the MODIS GPP data stream (Running et al., 2000) linking shortwave incoming radiation, minimum temperature and vapor pressure deficit. The model parameterization of Beer et al. (2010), based on Bayesian inversion against GPP time series from FLUXNET, is applied here. The terms in the MODIS-MOD17 biome-specific look-up table are used as priors. For regionalizing the model parameters, we stratify the results of the in situ calibration per vegetation type and bioclimatic class. As climatic drivers we use the ERAinterim data set and the same composite of fAPAR products as in MTE (Jung et al., 2011).

LPJmL is a dynamic vegetation model that mechanistically represents plant physiological and biogeochemical processes (Sitch et al., 2003) including the hydrological cycle (Gerten et al., 2004) and a process-based fire model (Thonicke et al., 2010). Vegetation is represented as plant functional types (PFTs), which are described by their bioclimatic limits, and morphological, phenological and physiological parameters. The model is also capable of simulating agricultural land (crop functional types, Bondeau et al., 2007) but for the present study, the model is applied in its natural vegetation mode. For each PFT, the model simulates photosynthesis (based on Farquhar et al. (1980) with adjustment of carboxylation capacity and leaf nitrogen seasonally and within the canopy profile; Haxeltine and Prentice, 1996) and respiration, as well as the allocation of accumulated carbon to the plant's compartments (leaves, stem, root and reproductive organs).

OCN is a land-surface model derived from the ORCHIDEE DGVM (Krinner et al., 2005), which prognostically simulates foliar area and $\mathrm{N}$ content and employs a twostream radiation scheme coupled to the process-based calculation of photosynthesis in light-limited and light-saturated chloroplasts within each canopy layer (Friend and Kiang, 2005).

AVG is the average of the above four data sets. Although in most cases we will report averaged results of MTE, MOD17+, LPJmL and OCN, we will also compute extremes on the averaged data set, assuming that averaging levels out artifacts of individual data sets and emphasizes common features.

The attribution of GPP extreme events to climatic drivers is based on temperature $(\mathrm{T})$ and precipitation $(\mathrm{P})$ data from bias-corrected ERA Interim (Dee et al., 2011, as used by the models predicting GPP), the water availability index (WAI), burned area (BA), and $\mathrm{CO}_{2}$ emissions from fires (FE, Giglio et al., 2010). WAI is a surrogate for soil moisture and was computed according to Prentice et al. (1993) using daily precipitation and potential evapotranspiration data from ERA Interim and a map of plant available water holding capacity from the Global Harmonized World Soil Database. The spatial resolution for all above data sets is $0.5^{\circ}$. T, P, WAI and all GPP data sets are available monthly from 1982 to 2011 , BA and FE from 1997 to 2010.

We use the following data sets to compare results obtained from the GPP data sets (in particular hot spots of extreme events and scaling behavior) with other remote sensing products. A composite of the fraction of absorbed photosynthetically active radiation (fAPAR, Jung et al., 2011) and the leaf area index (LAI, Liu et al., 2012) from 1982 to 2011 on a $0.5^{\circ}$ spatial and monthly temporal resolution, the enhanced vegetation index from MODIS (EVI, Huete et al., 2002) from 2001 to 2011 on a $0.5^{\circ}$ spatial and 8-day temporal resolution, and GPP from MODIS (MODISGPP, Running et al., 2004) from 2001 to 2011 on a $0.1^{\circ}$ spatial and 8 day spatial resolution.

We then define six areas as continental cutouts by concatenating selected regions of the SREX report of the IPCC (2012) (see also Fig. 2 in Zscheischler et al., 2013) as follows: North America 1-6, South America 7-10, Europe 1113, Africa 14-17, Asia 18-23, Oceania 24-26 (numbers are the SREX regions).

\subsection{Preprocessing}

We obtain anomalies by first subtracting linear trends and mean annual cycles at each pixel from all relevant variables, that is, T, WAI, EVI, fAPAR, LAI, and all GPP data sets.

\subsection{Extreme event identification}

In accordance with the IPCC climate extreme classifications (Seneviratne et al., 2012), we define extremes as the occurrence of certain values in the tails of the probability distribution of the anomalies. More specifically, extremes are defined as values outside a certain threshold $q$, which is given by a percentile on the absolute values of the anomalies (Fig. 1). The thresholds for each of the four data sets are chosen such that extremes (positive and negative together) comprise $1, \ldots, 10 \%$ of the anomalies at each continent separately. We then define an extreme event by spatiotemporally contiguous values being larger than $q$ (positive extremes) and smaller than $-q$ (negative extremes), respectively. To decide whether two elements in a 3-D data cube, so-called voxels (short for volumetric pixel, used for example in Neuroscience or computer gaming), are connected, different definitions are possible. Naturally, for a three-dimensional data set, connectivities of 6,18 and 26 are used. A connectivity of 6 means that only horizontal or vertical neighbors are considered as connected to it (each voxel has 6 horizontal and vertical neighbors). A connectivity of 18 means that all neighbors in the $3 \times 3 \times 3$ 


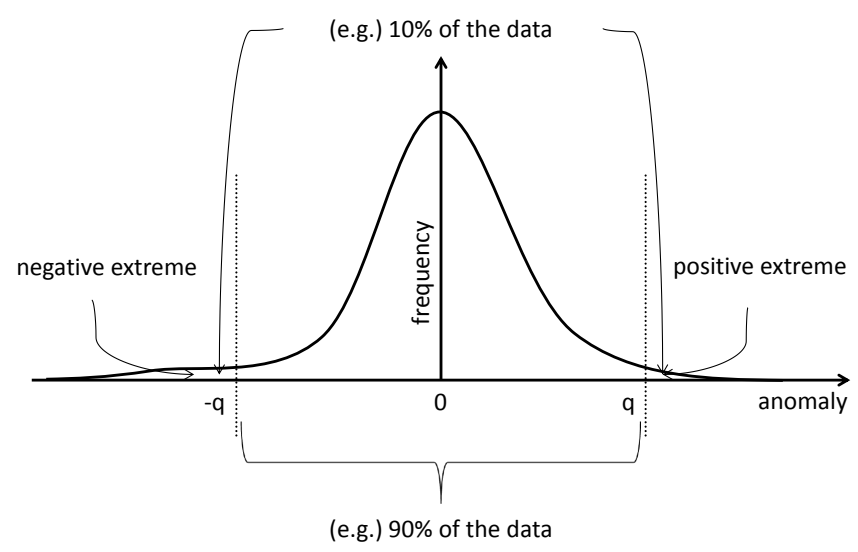

Figure 1. Sketch of how extremes are defined on GPP anomalies. A symmetric threshold $q$ is set such that $90 \%$ (as an example) of the data anomalies fall in between $-q$ and $q$. Those values which exceed the threshold are defined to be extreme. In this example the extremes are defined using the 10th-percentile definition (not to scale). Reprint of figure A2 in Zscheischler et al. (2014).

neighborhood of one voxel count as connected, excluding the 8 corners $(3 \times 3 \times 3=27-8$ corners - center $=18)$, while a connectivity 26 means that all 26 vertical, horizontal and diagonal neighbors are considered as connected to the central voxel $(27-1=26)$. Note that in principle the connectivity could also extend over more than one neighboring pixel (Lloyd-Hughes, 2012). Throughout most of this study, we will use a connectivity of 26 . We generally compute the largest 200 positive and negative GPP extreme events on each continent.

To evaluate the sensitivity of our method to some of the relevant parameters, we will analyze the scaling behavior of different temporal and spatial resolutions as well as different definitions of connectivity on the MODISGPP data set, which is available in high temporal and spatial resolution. To evaluate spatial patterns of hot spots we compare our results with the same extreme event detection approach on EVI, fAPAR, LAI and the mean of the four $0.5^{\circ} \mathrm{GPP}$ data sets.

\subsection{Nomenclature}

The integral of anomalies over the spatiotemporal domain of one GPP extreme event is called the overall impact of an event. Its spatial extent is the maximal spatial extent in $\mathrm{km}^{2}$, independent of the time. Duration is the maximal length of an event in months. An event computed using 5th-percentiles is called a 5th-percentile extreme.

\subsection{Statistics on extreme events}

We test whether the distributions of overall impacts and spatial extents of extreme events follow power laws as per the suggestions by Clauset et al. (2009). We assess whether positive and negative extreme events are equally large by dividing the $n$ largest negative events by the $n$ largest positive events. To study the asymmetry at pixel scale we subtract global maps of negative and positive extremes from each other (see below).

The impact of extreme events can be analyzed in time or space. For a temporal analysis, all anomalies in any extreme event (according to the definition under consideration) are summed over a region of interest for each time step. This summation then yields one regional time series of the total impact of the respective extreme events. Such time series of GPP extremes can then be correlated with, for example, the continental GPP anomaly in order to obtain the fraction of explained variance. Similarly, for an analysis in space, all anomalies in the extreme events are summed together for each location (pixel). A summation of this type leads to a map of the cumulative impact of the extreme events under consideration.

We compute the number of extreme events starting at each month in the year to analyze whether there is a seasonality in the occurrence of GPP extreme events. To assess which factors are most responsible for the overall impact of a GPP extreme event we correlate the overall impact of events against their spatial extent, duration and maximal anomaly. To investigate the influence of the resolution and connectivity on the power-law coefficient we perform a 3-way ANOVA using spatial resolution $\left(0.1^{\circ}, 0.5^{\circ}, 1^{\circ}\right)$, temporal resolution (8 days, 16 days, 1 month) and connectivity $(6,18,26)$ as factors.

\subsection{Attributing drivers to GPP extremes}

We follow Zscheischler et al. (2013) to identify drivers that possibly caused extremes in GPP separately for each continent. More specifically, for each GPP extreme event we compute the median of a driver variable over the same region. By shifting the event in time and computing such medians for each possible time shift, we obtain a test statistic for each driver variable and each GPP extreme event. We then compute $p$ values for the 200 largest negative 1st-percentile events of each GPP data set on each continent, where we use the drivers T, P, WAI, BA, FE and count a driver as "cause" if $p<0.1$. Accordingly, if a driver and GPP are not related one would expect on average $10 \%$ of the events being "caused" by that driver. The choice of the threshold is arbitrary and reflects how conservative the researcher wants to be. Our general conclusions are not sensitive to the specific choice of this parameter.

\subsection{Literature validation}

The mere number of extreme events hinders a comparison of the data sets on an event by event basis. Consequently, in this study we focus on the largest event of each data set per continent ( 5 data sets $\times 6$ continents $=30$ in total). In order to evaluate our detection approach against independent 

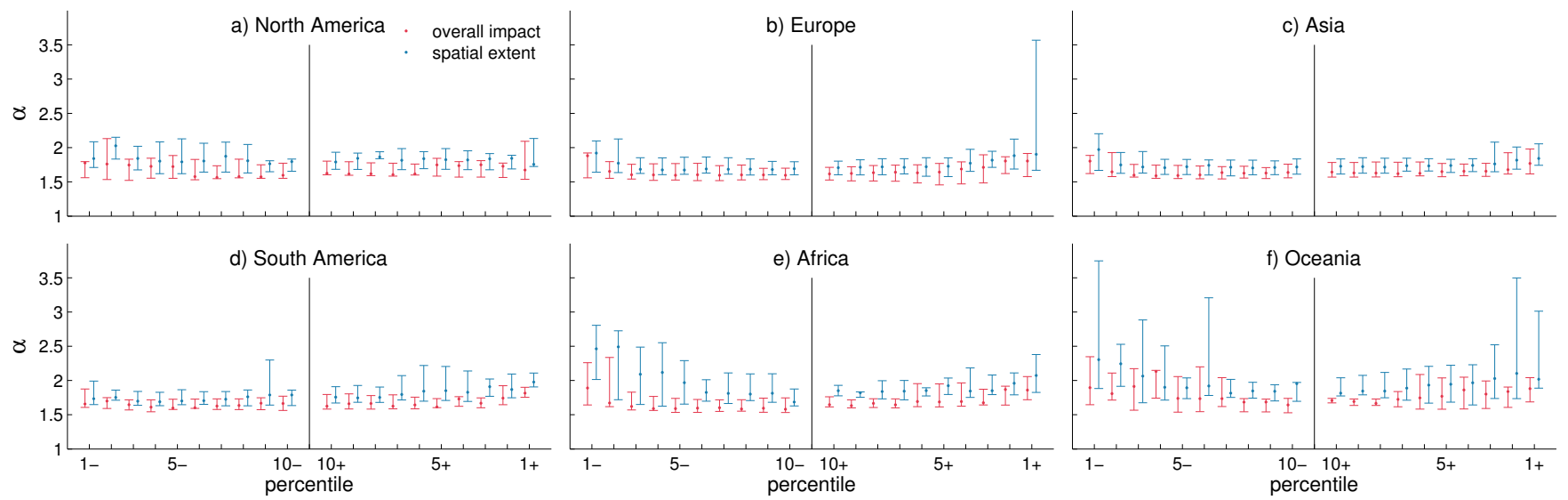

Figure 2. Values of the power-law exponent $\alpha$ for the overall impact (blue) and spatial extent (red) of extremes in GPP. Shown are the median (dot) and the range of the data sets MTE, MOD17+, LPJmL, OCN and AVG for the positive (+) and negative (-) extremes for the percentiles 1 to 10 .

evidence, we perform a systematic literature search. Our query was designed to find studies that either discuss climate extremes that could have caused a drastic decrease in GPP, or directly reported anomalous decreases in carbon uptake.

\section{Results and discussion}

\subsection{Extreme events in GPP are power-law distributed}

Mathematically, a variable follows a power law if it is drawn from a probability distribution

$p(x) \propto x^{-\alpha}$,

where $\alpha$ is the scaling parameter. Power laws have been studied in many branches of science. In ecology, power laws most often occur either as bivariate relationships (e.g., population density-body mass; (Marquet et al., 1990)) or frequency size distributions (e.g., body sizes; (Morse et al., 1985)), vegetation patches (Kéfi et al., 2007) fire magnitudes (Turcotte et al., 2002), or canopy gaps (Asner et al., 2013). Earlier attempts to describe disturbance events in form of power laws were restricted to their spatial extent (Fisher et al., 2008; Gloor et al., 2009; Kellner and Asner, 2009; Asner et al., 2013). It has recently been shown that the overall impacts of negative extreme events in fAPAR (Reichstein et al., 2013; Zscheischler et al., 2013) and GPP (Zscheischler et al., 2014) can also be well approximated by power laws at the global scale. Here, we look at each continent separately and also consider the spatial extent of extreme events.

Overall, the exponents $\alpha$ of the overall impacts of an event are lower than the exponents of the spatial extents (1.69 vs. 1.86 on average, Fig. 2). We also notice a slight upward trend for more extreme percentiles. Except for a few values, most of the power-law exponents of GPP extremes (defined by the 5th percentile or higher) are well in the range between
1.55-1.75, and 1.65-1.95 for overall impact and spatial extent, respectively. Hence, the values for the spatial extent fall in the range of exponents recently estimated for canopy gaps in tropical forests $(\alpha=1.83 \pm 0.09$; Asner et al., 2013). Low power-law exponents $(\alpha<2.0)$ imply that the distribution of extremes is largely dominated by few very large events, as has been discussed for the case of canopy gaps (Fisher et al., 2008; Asner et al., 2013).

Power laws can have a variety of origins (Newman, 2005; Sornette, 2006) and indeed, even in the described case of extreme spatiotemporal events, we can think of a series of plausible explanations. Because extreme events are computed using values exceeding a certain threshold, thresholding of stochastic processes (Touboul and Destexhe, 2010) or the theory of large deviation (Varadhan, 1966; Sornette, 2006) might provide reasonable explanations. It is known in ecology that power laws can emerge from a complex interplay of spatial interactions (Pascual and Guichard, 2005; Pueyo et al., 2010). For multidimensional lattices, percolation theory (Bollobas and Riordan, 2006) predicts that the size distribution of random clusters can follow a power law even without any spatial interactions. Whether the emergent power laws for overall impact and spatial extent arise from a combination of the above-mentioned mechanisms, or whether there is even a different mechanism generating these, cannot be conclusively resolved here and needs further investigation.

To understand the importance of individual extreme events, we investigate how much of each continent's interannual variability in GPP can be explained by extremes in GPP. It has been shown that at global scale, about 200 positive and negative 10th-percentile extreme events can explain nearly $80 \%$ of the global anomaly (Zscheischler et al., 2014). On the continental level, 50 positive and negative events are enough to obtain an averaged correlation coefficient, with continental anomaly between 0.88 (Asia) and 0.95 (Oceania) (Fig. 3). 


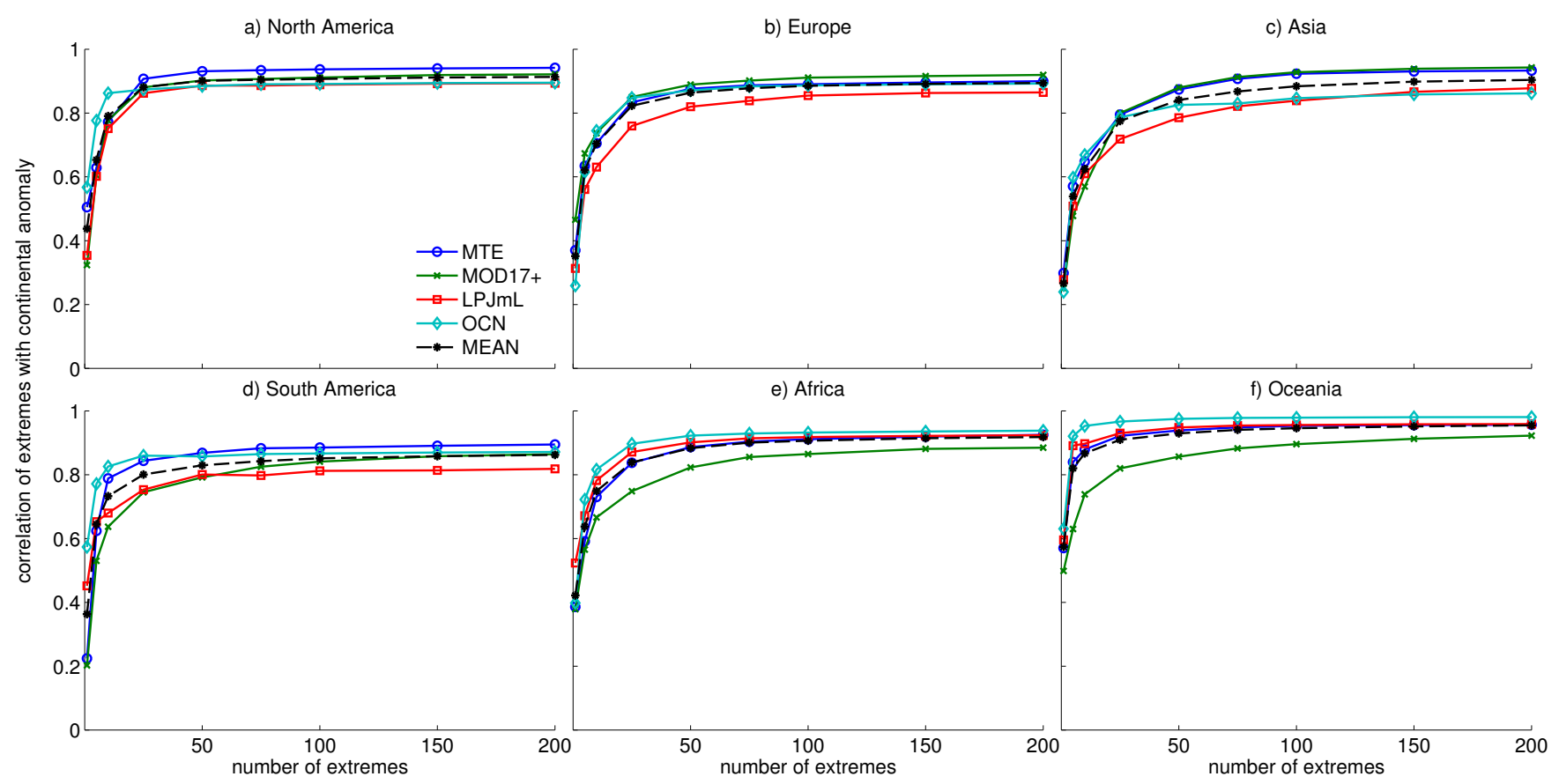

Figure 3. Correlations of 10th-percentile extremes (positive and negative) with the continental GPP anomalies. Depicted are the correlation coefficients for the data sets MTE (blue circles), MOD17+ (green cross), LPJmL (red square), OCN (cyan diamond). The dashed black line shows the mean of the correlation coefficients of the four data sets.

For 1st-percentile extremes the spatial extent is the dominating factor (as already mentioned in Reichstein et al., 2013), while the duration and maximal anomaly play a minor role. This relation changes very little throughout the continents (Fig. 4). For 10th-percentile extremes, the duration gains on importance and has similarly high correlations with overall impact as the spatial extent (not shown).

\subsection{Global distribution of GPP extremes}

The averaged map of an average year of the 200 largest negative 10th-percentile GPP extreme events computed for each continent is visually nearly identical with the averaged map for the globally largest 1000 extreme events (Fig. 5, cf. figure 3a in Zscheischler et al., 2014). We find that mostly savannas and grasslands experience large-scale extremes in GPP. The regions which on average experience the largest negative GPP extreme events at global scale include Caatinga (Brazil), the Pantanal (Brazil), the Great Plains (US), the grasslands connecting Kenya, Tanzania and Uganda (Africa), Highveld (South Africa), the Indus-Ganga Plain (India), and eastern Australia.

Comparing the impacts across continents reveals that extremes in GPP are largest in Asia (on average 0.87 $\mathrm{Pg} \mathrm{C} \mathrm{yr}^{-1}$ for 10th-percentile extremes, ranging from $0.50 \mathrm{Pg} \mathrm{C} \mathrm{yr}^{-1}$ in MOD17+ to $1.35 \mathrm{Pg} \mathrm{C} \mathrm{yr}^{-1}$ in LPJmL) and lowest in Europe (on average $0.23 \mathrm{PgC} \mathrm{yr}^{-1}$ for 10th-percentile extremes, ranging from $0.13 \mathrm{PgC} \mathrm{yr}^{-1}$ in MTE to $0.41 \mathrm{PgC} \mathrm{yr}^{-1}$ in LPJmL, Fig. 6a-f). The overall impact of extreme events in
GPP obviously depends on the size of the continent. The spread between the data sets is similar for each continent. However, in all continents the two models (LPJmL and OCN) exceed the two data-driven approaches (MTE and MOD17+) by a factor of at least two. Studies that compare model and data-driven GPP products found that the interannual variability of GPP is generally lower in MTE compared to carbon cycle models (Jung et al., 2011; Keenan et al., 2012; Piao et al., 2013). In South America, the two models agree very well, while in Europe and Africa the two data driven approaches nearly coincide (Fig. 6b-d). The magnitude of extremes in the averaged data set AVG lies at the lower range of the four other data sets. The averaging process levels out the tails of the distributions of the anomalies of the individual data sets (where those do not agree among each other) and hence contains less strongly pronounced extremes, as can also be seen from a histogram of the anomalies (not shown). The difference between the averaged extremes and the extremes of the averaged data set (Fig. 7) highlights again that extremes in AVG are generally smaller. Yet in tropical areas, in particular in densely vegetated regions, the extremes in AVG exceed the averaged extremes of the individual four data sets. This suggests that the data sets agree rather well in densely vegetated regions, albeit at the lower magnitude of extremes.

Negative GPP extreme events mainly start in summer, both in the Northern and Southern Hemisphere, except for Oceania (Fig. 8). This pattern is much stronger in the northern continents, presumably because of less pronounced seasonal 

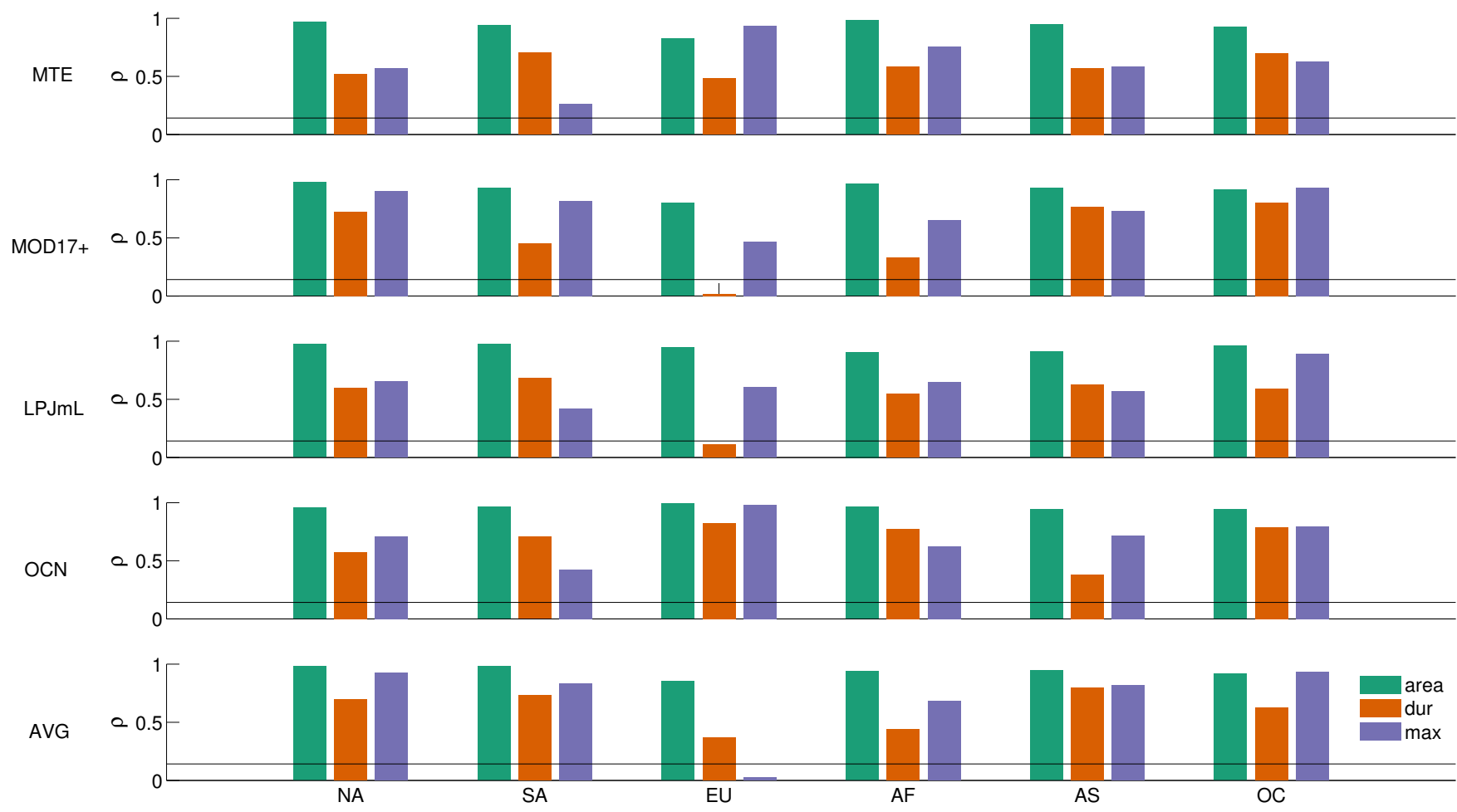

Figure 4. Correlations of spatial extent (green), duration (orange) and maximal anomaly (purple) of GPP extreme events with their overall impacts. Depicted are the correlations of extremes on all continents and the data sets MTE, MOD17+, LPJmL, OCN and AVG.

differences in the tropical regions, and the more land area in northern latitudes than in southern latitudes. For South America and Africa the increasing number of extremes coincides with the end of the dry season and with the wet season (ONDJ).

\subsection{Positive extremes offset negative extremes only partly}

It has been shown recently that at the global scale negative extreme events in GPP are larger than positive extremes (Zscheischler et al., 2014). One question we want to address here is if this observations holds for all continents. We find that the observed global asymmetry seems to be mainly generated by asymmetries in South America and Europe (Fig. 6h and i). In Africa and Asia, however, positive and negative GPP extremes are balanced, whereas in Oceania the positive extremes are slightly larger (Fig. 6j-1). The averaged data set $\mathrm{AVG}$, in contrast, exhibits a strong asymmetry towards larger negative GPP extreme events for all continents except Asia (Fig. 6h-1).

Figure 9 shows an average of the pixel-wise difference between the largest 200 positive and negative 10th-percentile GPP extreme events in MTE, MODSI17+, LPJmL and OCN (a), and the pixel-wise difference between the largest 200 positive and negative 10th-percentile GPP extreme events of AVG (b), respectively. The patterns are similar in most re- gions of the world. The asymmetry between negative and positive extremes in GPP appears as a robust feature, persisting throughout the averaging process. Although it seems that overall the regions with larger negative extremes do not dominate at global scale (Fig. 9, blue and red occupy a similar amount of land surface), their magnitude is often much larger. Also, in most tropical regions negative extremes are dominant (red dominates in tropical areas).

Potential reasons for the observed asymmetry have been discussed in Zscheischler et al. (2014) and include the "slow in, rapid out" principle (Körner, 2003) and asymmetric driving mechanisms (Mueller and Seneviratne, 2012). Yet another possible driver of the observed asymmetry might be the asymmetric behavior of the El Niño-Southern Oscillation (ENSO). The warm and dry phases (El Niño) are often longer and more intense than its cold counterparts (La Niña), with far-reaching climatological and ecological impacts (An and Jin, 2004). In regions where positive extremes prevail, the "pulse-response" paradigm (Huxman et al., 2004; Chen et al., 2009) might serve as an explanation. Systems that are generally unproductive can experience growth phases which are triggered by rain pulses. Especially arid and semiarid ecosystems exhibit this behavior, whose areal extent coincides well with the blue areas in Fig. 9. 


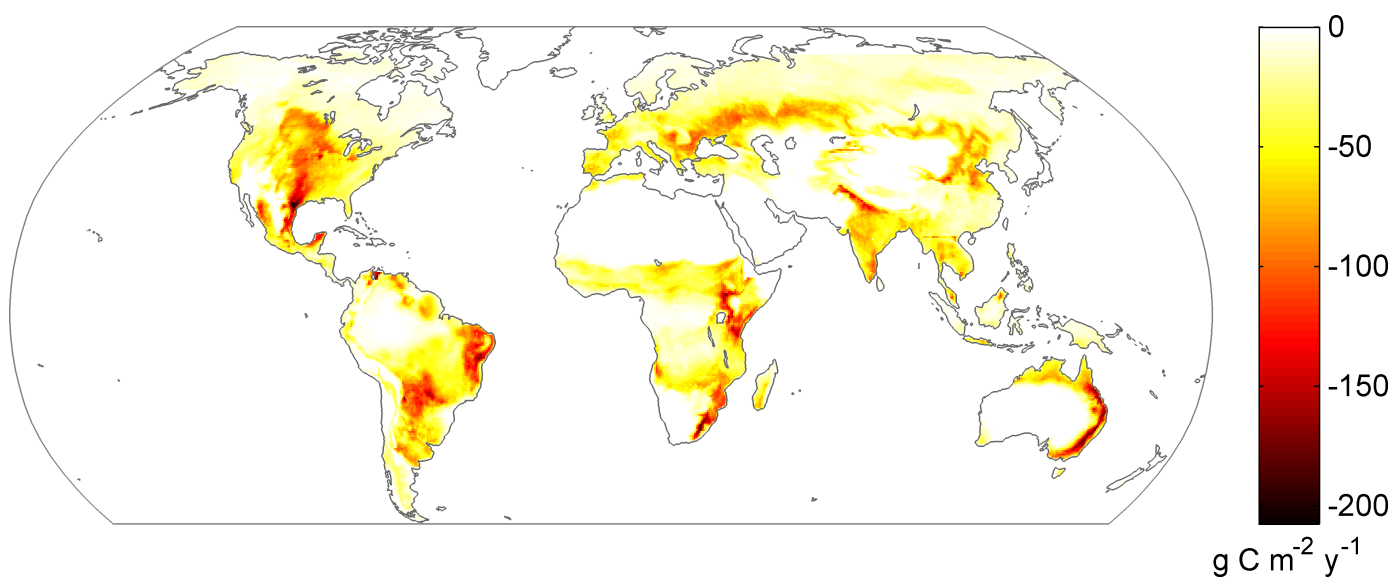

Figure 5. Global averaged map of negative 10th-percentile extreme events in GPP. The largest 200 10th-percentile extremes in GPP for each continent and the four data sets MTE, MOD17+, LPJmL and OCN were computed and then averaged to obtain the typical impact of GPP extreme events per year. Compare with Figure 3A in Zscheischler et al. (2014) for an analysis at the global scale.

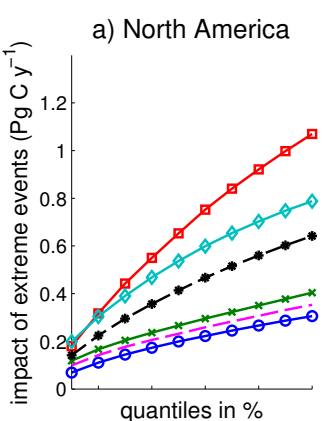

g) North America

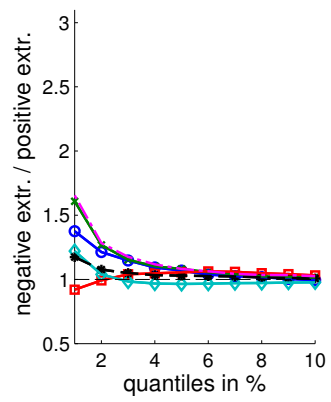

b) South America

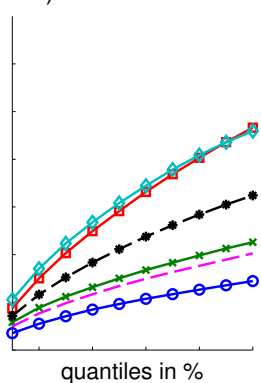

h) South America

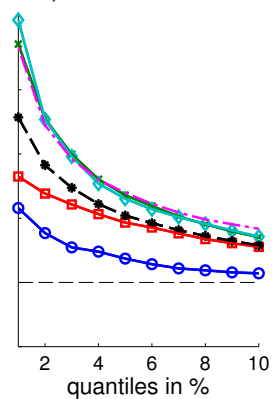

c) Europe

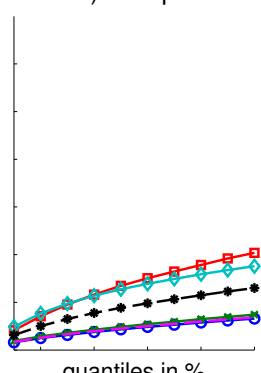

i) Europe

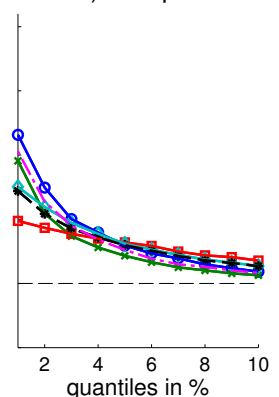

d) Africa

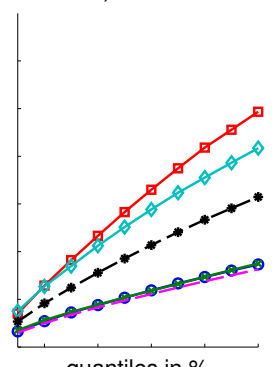

j) Africa

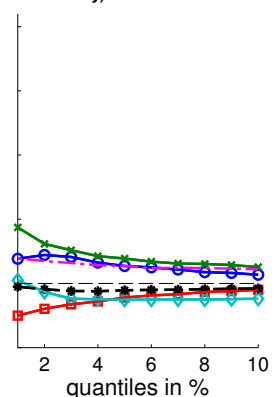

e) Asia

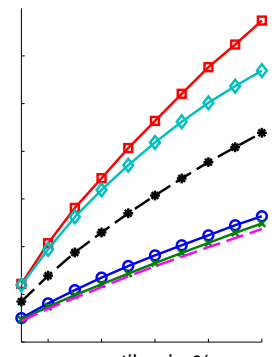

quantiles in \%

k) Asia

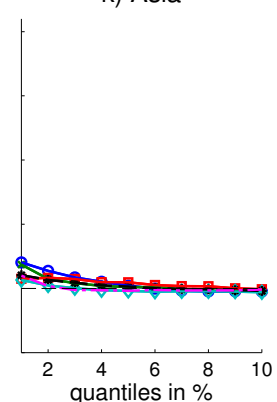

f) Oceania

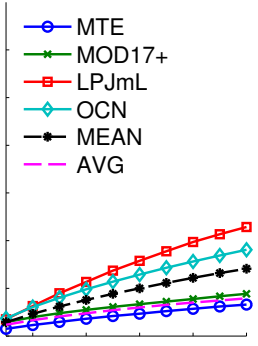

quantiles in \%

I) Oceania

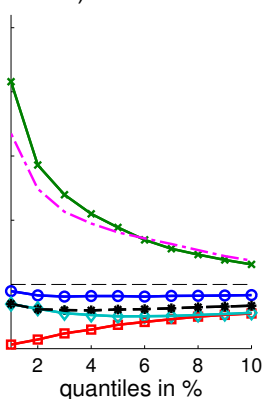

Figure 6. Overall impact and asymmetry of GPP extreme events. Depicted are the four different GPP data sets (MTE, MOD17+, LPJmL, OCN), the average of the results of the four (MEAN), and the results for the averaged data set (AVG). (a-f) Sum of the overall impact of the largest 200 extreme events in GPP for each continent using the percentiles 1 to 10. (g-l) Quotient between 200 largest negative and 200 largest positive extreme events in GPP for each continent using the percentiles 1 to 10. 


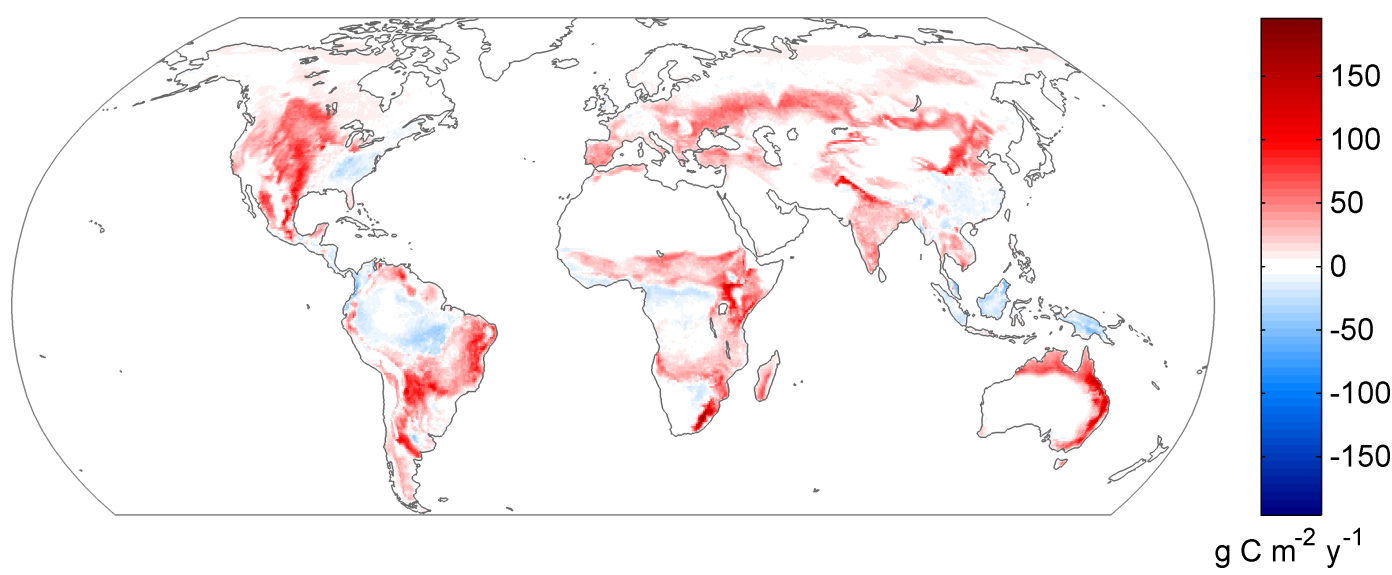

Figure 7. Difference between negative GPP extreme events of the averaged data set AVG and averaged negative GPP extreme events of the four data sets MTE, MOD17+, LPJmL, and OCN. Depicted is the difference in impact per year. For each continent and each data set the 200 largest negative 10th-percentile GPP extreme events were computed and then integrated over time. Red areas imply smaller extreme events in AVG (less negative impact).
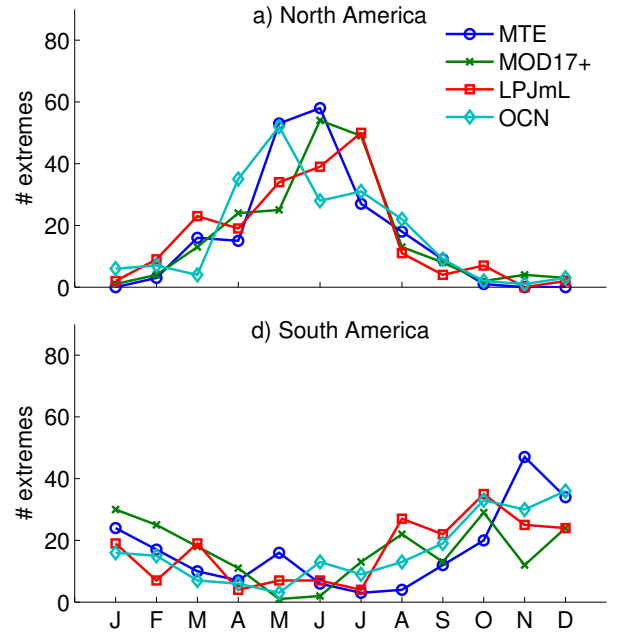

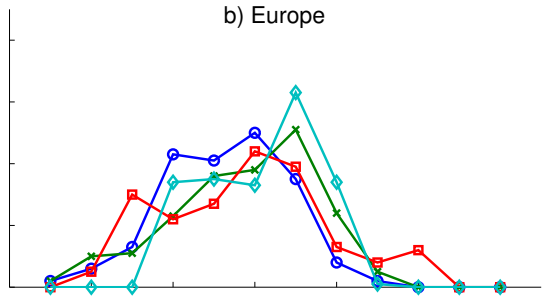

e) Africa

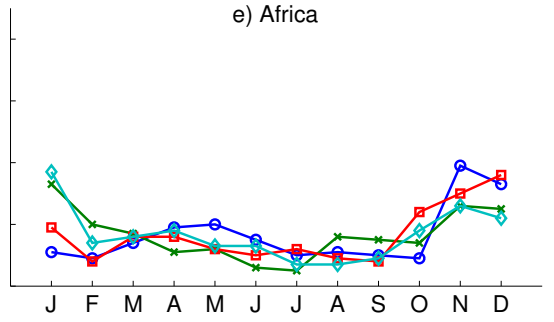

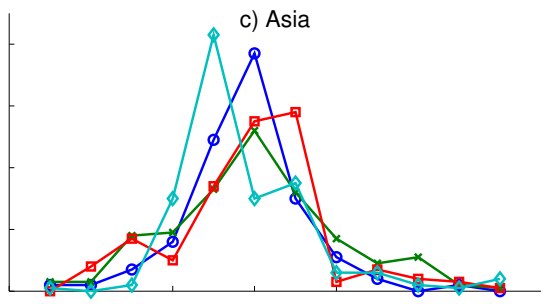

f) Oceania

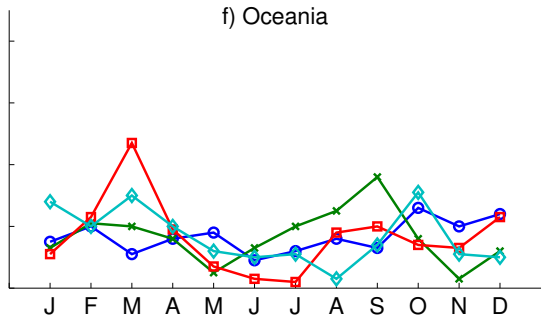

Figure 8. Number of GPP extreme events starting per month for the largest 200 1st-percentile extremes in GPP for each continent and the data sets MTE, MOD17+, LPJmL, OCN.

\subsection{Influence of resolution and connectivity on the scaling parameter}

One may remark that the identified scaling behavior (the exponents of the power law) of GPP extremes is partly an effect of spatial resolution and chosen connectivity (cf. Sect. 3.1). In order to investigate this issue, we use MODISGPP to analyze the sensitivity of the power-law exponent regarding the spatial and temporal resolution, because MODISGPP is available on higher resolutions than the four data sets we analyzed before. We can detect a dependence of $\alpha$ to the spatial and temporal resolution as well as to the connectivity (3-way ANOVA, $p<0.05$ in $81 \%$ and $69 \%$ of the cases for overall impact and spatial extent, respectively), but the effects are remarkably small. The mean over the exponent $\alpha$ for the distribution of overall impacts for all continents and all configu- rations is $1.87 \pm 0.09$. For the spatial extent we obtain a mean of $1.97 \pm 0.14$. This suggests that the emergent power-law behavior in overall impact and spatial extent is a robust feature of extreme events in GPP.

\subsection{Water scarcity as the dominant driver for negative extreme events}

Recent studies identified water scarcity as the globally dominant driver for negative extreme GPP events (Reichstein et al., 2013; Zscheischler et al., 2014). Breaking down the analysis to the continental scale supports these findings. The patterns for the different data sets look alike (Fig. 10), although differing slightly in magnitude. GPP in LPJmL is most sensitive to droughts (on average $76 \%$ of the GPP extremes could be associated with low levels of WAI; Fig. 10, 


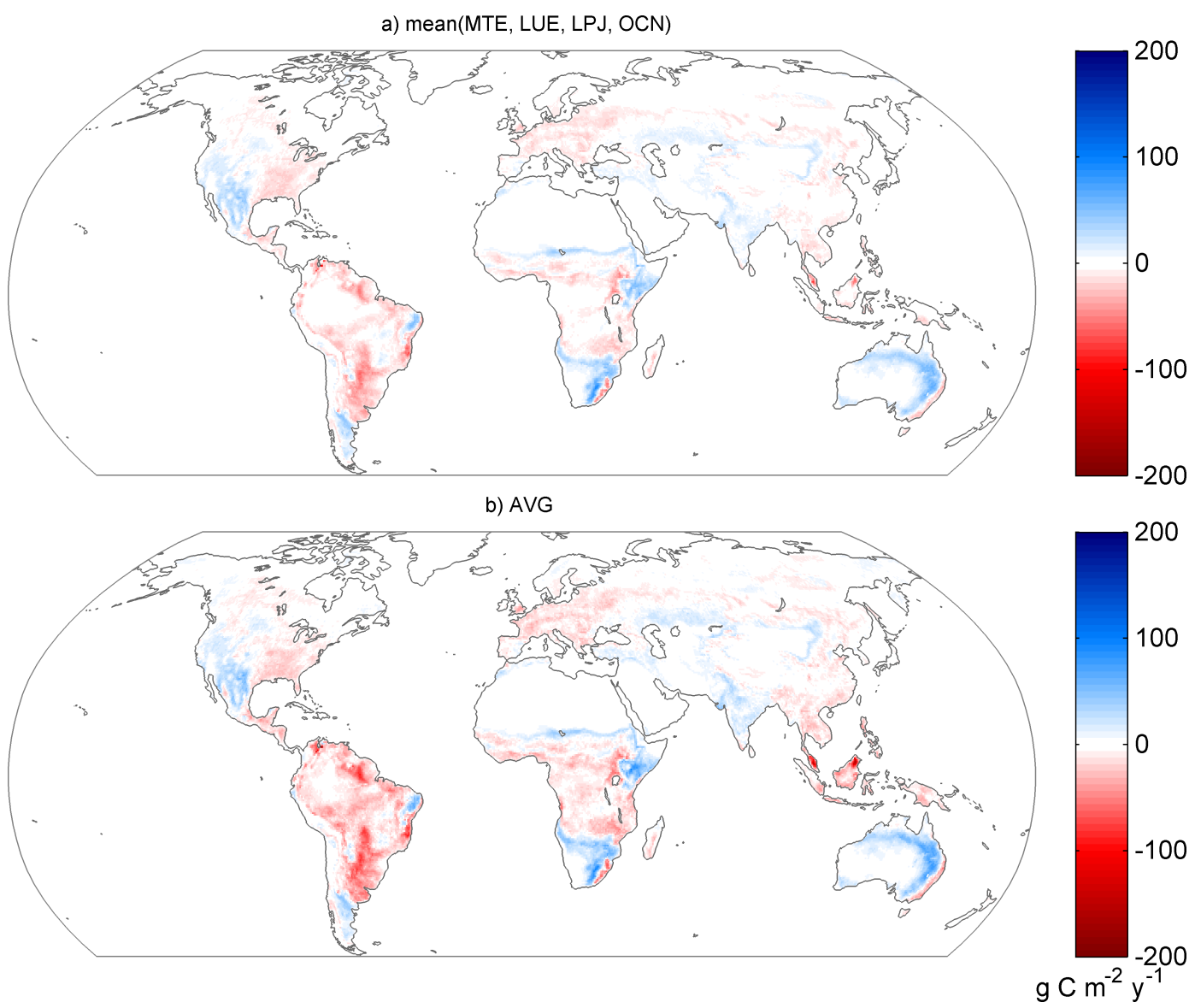

Figure 9. Pixel-wise difference between the 200 largest positive and the 200 largest negative extreme events. In the red areas negative extremes dominate. (a) Averaged difference between GPP extreme events in the four data sets MTE, MOD17+, LPJmL and OCN. (b) Difference between GPP extreme events in the averaged data set AVG.

orange bars). However, there are also some differences between continents. In Europe, GPP does not seem to be as susceptible to droughts as in the other continents. Here we find on average $20 \%$ fewer associations of GPP extremes with low values of WAI compared to other continents. Instead, cold spells are associated with negative GPP extremes more often than random, similarly to Oceania (on average $10 \%$ and $11 \%$ more often than random, respectively; Fig. 10, blue bars. Random is here defined as the expected fraction of events attributed to any driver if the variables were unrelated $(=10 \%))$. In contrast, in North America high temperatures lead more often to large reductions in GPP (10\% more than random; Fig. 10, red bars). Intense precipitation events play a significant role in reducing GPP in South America and Oceania (6\% and $7 \%$ more than random, respectively; Fig. 10, green bars), whereas fires are an important driver in South America, Europe, Africa and Oceania, (14\%, $11 \%$, $9 \%$ and $18 \%$ more than random, respectively; Fig. 10, yellow bars). Note that not all negative GPP events can be attributed to the driver variables here. Other drivers like wind throw, insect outbreaks, intensive grazing, logging, and hu- man deforestation, which are not considered in this study, might likewise reduce carbon uptake drastically (Reichstein et al., 2013). We also do not consider effects of so-called compound events in climate here (Seneviratne et al., 2012; Leonard et al., 2013), in other words, events in which a constellation of two or more drivers is extreme in the multivariate variable space which can lead to possibly large changes in carbon uptake. In Europe, the number of unexplained events is largest (Fig. 10, brown bars). The attribution patterns of the averaged data set AVG agree very well with the other data sets.

\subsection{Validation with literature}

In general it is difficult to validate purely data-based analyses if no ground truth is available. Table 1 summarizes the timing, approximate region, probable reason, and a reference (where one could be found) for the largest negative 1stpercentile event on each continent. Out of all 30 events, only 2 could not be associated with a literature reference (eastern Europe, 1987 in MTE, and eastern Malaysia, Oceania, 20022004 in MOD17+). However, given the good agreement of 

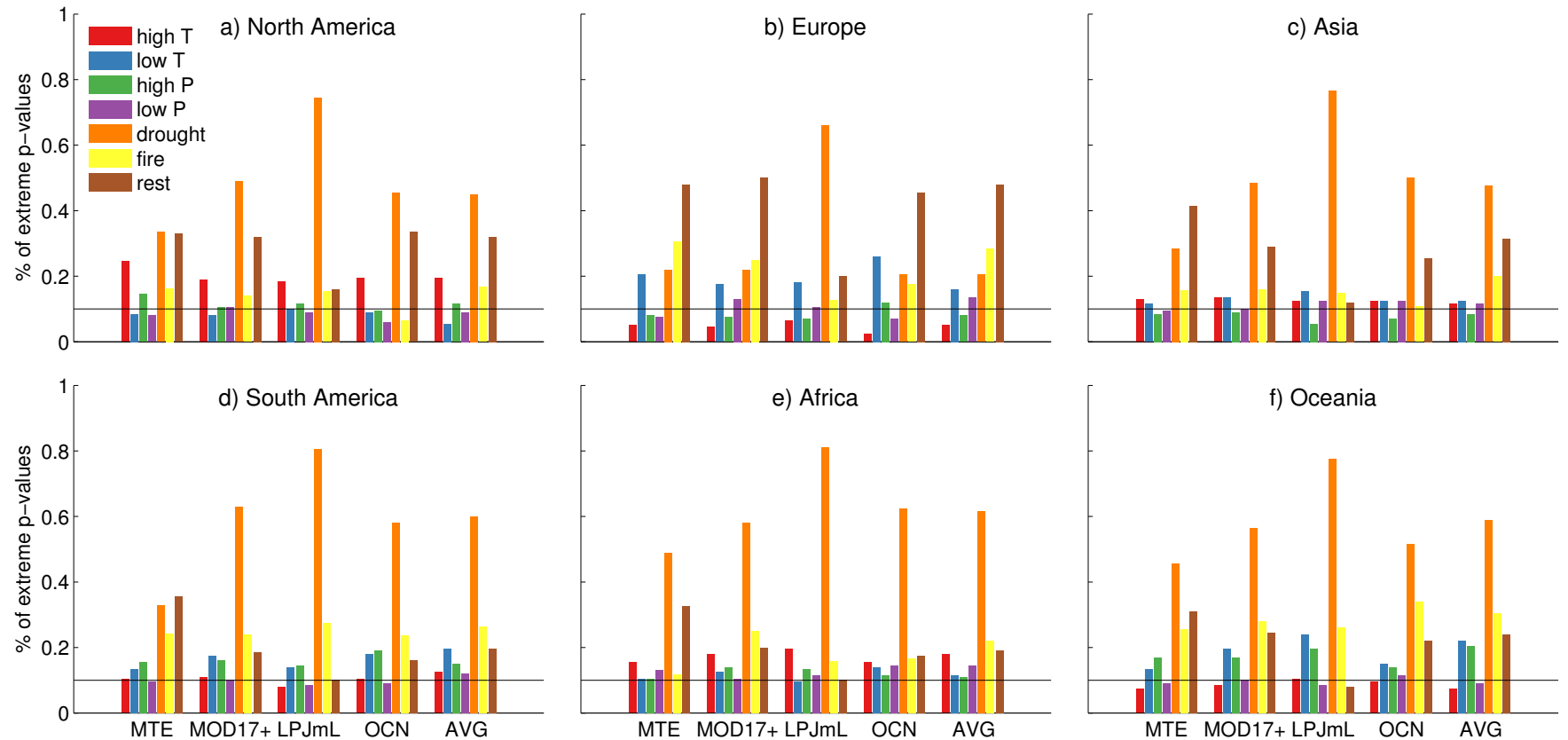

Figure 10. Percentage of extreme $p$ values $(p<0.1)$ of the 200 largest negative 1 st-percentile GPP extreme events for each of the six continents, all four data sets and the variables high and low temperature ( $T$, red and blue), high and low precipitation ( $P$, green and purple), low water availability (drought, orange), and high burned area or fire emissions (fire, yellow). The horizontal line depicts the significance threshold (0.1), that is, the percentage of events which are expected to have $p$ values below 0.1 if the data were random. The last bar (rest, brown) depicts the fraction of events that could not be attributed to any of the former variables.

Table 1. Approximate location, timing and reference (ref) for the largest negative 1st-percentile GPP extreme events from each of the five data sets MTE, MOD17+, LPJmL, OCN and AVG on each continent.

\begin{tabular}{|c|c|c|c|c|c|}
\hline & MTE & MOD17+ & LPJmL & $\mathrm{OCN}$ & AVG \\
\hline $\begin{array}{l}\text { NA } \\
\text { where } \\
\text { what } \\
\text { ref }\end{array}$ & $\begin{array}{l}2011 \\
\text { Texas, South West US } \\
\text { drought } \\
\text { (Coumou and Rahmstorf, 2012) }\end{array}$ & $\begin{array}{l}1988 \\
\text { Midwestern US } \\
\text { drought } \\
\text { (Namias, 1991) }\end{array}$ & $\begin{array}{l}2006 \\
\text { Great Plains } \\
\text { drought } \\
\text { (Dong et al., 2011) }\end{array}$ & $\begin{array}{l}2006 \\
\text { Great Plains } \\
\text { drought } \\
\text { (Dong et al., 2011) }\end{array}$ & $\begin{array}{l}2011 \\
\text { Texas, South West US } \\
\text { drought } \\
\text { (Coumou and Rahmstorf, 2012) }\end{array}$ \\
\hline $\begin{array}{l}\text { SA } \\
\text { where } \\
\text { what } \\
\text { ref }\end{array}$ & $\begin{array}{l}\text { 1992-1993 } \\
\text { NE Brazil } \\
\text { drought } \\
\text { (Rao et al., 1995) }\end{array}$ & $\begin{array}{l}2010 \\
\text { Amazon } \\
\text { drought } \\
\text { (Lewis et al., 2011) }\end{array}$ & $\begin{array}{l}\text { 1995-1996 } \\
\text { Northern Argentina } \\
\text { drought } \\
\text { (Minetti et al., 2009) }\end{array}$ & $\begin{array}{l}\text { 2004-2006 } \\
\text { Eastern Amazon } \\
\text { drought } \\
\text { (Anderson et al., 2010) }\end{array}$ & $\begin{array}{l}2010 \\
\text { SE Amazon } \\
\text { drought } \\
\text { (Lewis et al., 2011) }\end{array}$ \\
\hline $\begin{array}{l}\text { EU } \\
\text { where } \\
\text { what } \\
\text { ref }\end{array}$ & $\begin{array}{l}1987 \\
\text { Eastern Europe }\end{array}$ & $\begin{array}{l}2003 \\
\text { Central Europe } \\
\text { drought, heat wave } \\
\text { (Ciais et al., 2005) }\end{array}$ & $\begin{array}{l}1992 \\
\text { Central-eastern Europe } \\
\text { drought } \\
\text { (Siwkcki and Ufnalski, 1998) }\end{array}$ & $\begin{array}{l}2002 \\
\text { Southwestern Russia } \\
\text { cold spell, flooding } \\
\text { (Waple and Lawrimore, 2003) }\end{array}$ & $\begin{array}{l}2003 \\
\text { Central Europe } \\
\text { drought, heat wave } \\
\text { (Ciais et al., 2005) }\end{array}$ \\
\hline $\begin{array}{l}\text { AF } \\
\text { where } \\
\text { what } \\
\text { ref }\end{array}$ & $\begin{array}{l}\text { 1984-1985 } \\
\text { Sahel } \\
\text { drought, famine } \\
\text { (Rojas et al., 2011) }\end{array}$ & $\begin{array}{l}\text { 1996-1997 } \\
\text { East Africa } \\
\text { drought } \\
\text { (Galvin et al., 2001) }\end{array}$ & $\begin{array}{l}1992 \\
\text { South Africa } \\
\text { drought } \\
\text { (Rouault and Richard, 2003) }\end{array}$ & $\begin{array}{l}\text { 1991-1994 } \\
\text { East Africa } \\
\text { drought } \\
\text { (Galvin et al., 2001) }\end{array}$ & $\begin{array}{l}\text { 1996-1997 } \\
\text { East Africa } \\
\text { drought } \\
\text { (Galvin et al., 2001) }\end{array}$ \\
\hline $\begin{array}{l}\text { AS } \\
\text { where } \\
\text { what } \\
\text { ref }\end{array}$ & $\begin{array}{l}2010 \\
\text { Russia } \\
\text { heat wave } \\
\text { (Barriopedro et al., 2011) }\end{array}$ & $\begin{array}{l}2010 \\
\text { Russia } \\
\text { heat wave } \\
\text { (Barriopedro et al., 2011) }\end{array}$ & $\begin{array}{l}2010 \\
\text { Russia } \\
\text { heat wave } \\
\text { (Barriopedro et al., 2011) }\end{array}$ & $\begin{array}{l}2010 \\
\text { Russia } \\
\text { heat wave } \\
\text { (Barriopedro et al., 2011) }\end{array}$ & $\begin{array}{l}2010 \\
\text { Russia } \\
\text { heat wave } \\
\text { (Barriopedro et al., 2011) }\end{array}$ \\
\hline $\begin{array}{l}\text { OC } \\
\text { where } \\
\text { what } \\
\text { ref }\end{array}$ & $\begin{array}{l}2002-2003 \\
\text { SE Australia } \\
\text { Millennium drought } \\
\text { (Leblanc et al., 2009) }\end{array}$ & $\begin{array}{l}2002-2004 \\
\text { Eastern Malaysia }\end{array}$ & $\begin{array}{l}\text { 1982-1983 } \\
\text { SE Australia } \\
\text { drought } \\
\text { (Myneni et al., 1996) }\end{array}$ & $\begin{array}{l}\text { 1982-1983 } \\
\text { SE Australia } \\
\text { drought } \\
\text { (Myneni et al., 1996) }\end{array}$ & $\begin{array}{l}2002-2003 \\
\text { SE Australia } \\
\text { Millennium drought } \\
\text { (Leblanc et al., 2009) }\end{array}$ \\
\hline
\end{tabular}


a) EVI

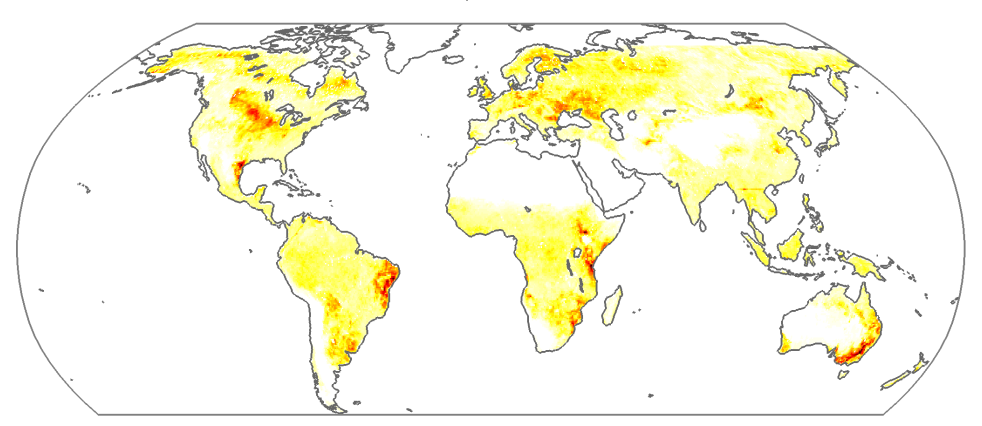

b) FAPAR

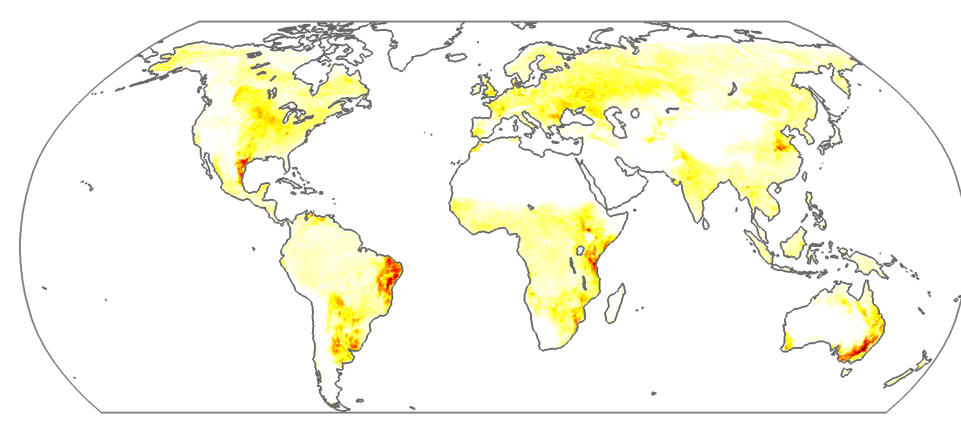

c) LAI

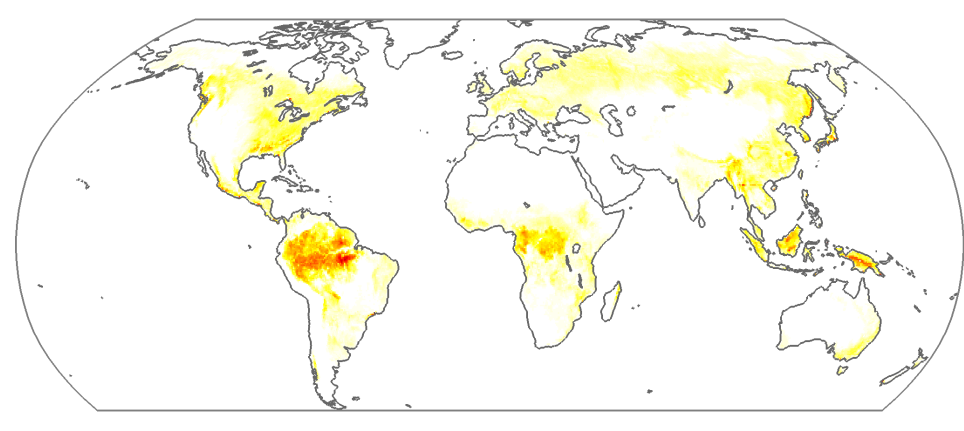

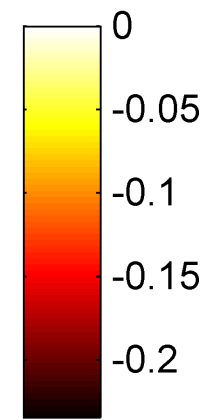

$\Delta E V I m^{-2} y^{-1}$

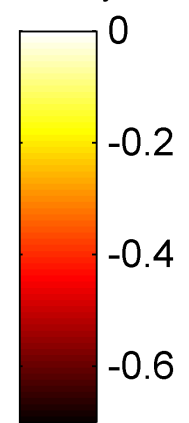

$\triangle$ FAPAR $\mathrm{m}^{-2} \mathrm{y}^{-1}$

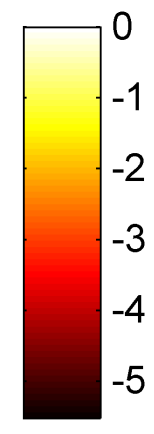

$\Delta \mathrm{LAl} \mathrm{m} \mathrm{m}^{-2} \mathrm{y}^{-1}$

Figure 11. Average impact per year due to negative extreme events in (a) EVI (2001-2011), (b) FAPAR (1982-2011), and (c) LAI (19822011). On each continent the 200 largest negative 10th-percentile extremes were computed and merged to obtain a global map. The maps depict the decrease in the respective variable compared to the average year generated by extreme events in that variable.

the other events compared to literature evidence, we can consider these two events as examples of overlooked continentally relevant GPP extremes. In the Asian cutout, all data sets agree and we detect the big heat wave of 2010 in Russia (Barriopedro et al., 2011) as the largest event. Of course, the largest event in one data set might appear as the second largest in another. The two models agree in three of the six continents. It is noteworthy that the averaged data set finds mostly well-known extreme events, for instance the year of extreme weather in the United States in 2011 (Coumou and Rahmstorf, 2012), the Amazon drought of 2010 (Lewis et al., 2011), the European and Russian heat waves in 2003 (Ciais et al., 2005) and 2010 (Barriopedro et al., 2011), as well as the extreme drought in southeastern Australia at the be- ginning of the 21st century, also known as the "Big Dry" (Leblanc et al., 2009; Ummenhofer et al., 2009). The good matching between the AVG and well-known events from the literature is encouraging because it demonstrates that averaging different data sets with high uncertainties can result in a reasonably good representation of large-scale extreme events. An example for such an averaging for an biosphereatmosphere flux is a recently presented data product of evapotranspiration (ET, Mueller et al., 2013).

\subsection{Comparison with other data sets}

In order to further test the robustness of our findings, we compare the global patterns of extremes in GPP from the four 
data sets MTE, MOD17+, LPJmL and OCN with spatiotemporal extremes in other remote sensing products, in particular EVI, FAPAR, and LAI. All these earth observations have a three-dimensional (spatiotemporal) structure, albeit with different spatial and temporal resolutions, and hence we can apply the same extreme event detection method here, as described in Sect. 2.3. However, note that units are not transferable into changes in carbon uptake. The patterns for EVI and FAPAR (Fig. 11a and b, respectively) show good agreement with the overall patterns of GPP extreme events (Fig. 5) in Brazil, the Great Plains, eastern Europe, Tanzania/Kenya, South Africa and southeastern Australia. The hot spot in the Indus-Ganga Plain (India) is not visible in EVI and FAPAR. LAI shows strongly pronounced extremes in tropical forests (Amazon and Congo basins, Indonesia, Fig. 11c). LAI values in tropical forests vary over a much wider range compared to other biomes (Liu et al., 2012). This in turn leads to a much larger interannual variability in these areas, resulting in larger extremes.

\section{Conclusions}

We present a detailed analysis of spatiotemporal contiguous extremes in different data sets of GPP over the last 30 years and compare their impacts across continents. We show that the overall impact and spatial extent of extreme events in GPP follow power-law distributions and confirm earlier findings that water scarcity has to be regarded as the key driver of negative GPP extremes. However, we identify pronounced regional deviations from this global picture. Depending on the continent, fires (all continents except North America and Asia), high temperatures (North America), cold spells (Europe and Oceania), and intense precipitation events (South America and Oceania) can also provoke major decreases in GPP. A comparison of these findings with a literature survey and a validation with remotely sensed data sets, including EVI and fAPAR, generally supports our identification of the largest GPP extremes, and confirms the reported geographical distributions.

The research on extreme events in both climate variables and vegetation indexes is important to fully understand carbon cycle variability and ultimately carbon cycle-climate feedbacks. While in the past, changes in the mean were the primary focus of research, today studies on climate extremes and their impacts on the terrestrial biosphere are mounting. This change in focus might have been driven by the insight that changes in extreme events can alter the functioning of terrestrial ecosystems more strongly than changes in the mean (Jentsch and Beierkuhnlein, 2008). However, before accessing changes in extremes (including their impacts) we first have to gain a more profound understanding on how present day climate extremes affect the functioning of terrestrial ecosystems. In this contribution we corroborate the importance of extreme events for interannual variability of GPP at continental scales. Yet, despite the prominence of water availability as the most important driver for extremes in GPP on all continents, the susceptibility to other drivers such as fires and extreme temperatures largely differs across continents. The reason for that might lie in different vulnerabilities of the dominant ecosystems on each continent towards extreme environmental conditions.

Acknowledgements. This study was supported by the projects CARBO-Extreme (grant agreement no. 226701) and GEOCARBON (grant agreement no. 283080) of the European Community's 7th framework program. We thank Sönke Zaehle for providing data from OCN and Martin Jung for providing upscaled fields of GPP (MTE). Natalia Ungelenk helped with the literature review behind Table 1. JZ is part of the International Max Planck Research School for global Biogeochemical Cycles (IMPRS-gBGC).

The service charges for this open access publication have been covered by the Max Planck Society.

Edited by: M. Bahn

\section{References}

An, S.-I. and Jin, F.-F.: Nonlinearity and asymmetry of ENSO, J. Climate, 17, 2399-2412, 2004.

Anderson, L. O., Malhi, Y., Aragão, L. E., Ladle, R., Arai, E., Barbier, N., and Phillips, O.: Remote sensing detection of droughts in Amazonian forest canopies, New Phytol., 187, 733-750, 2010.

Arnone, J. a., Verburg, P. S. J., Johnson, D. W., Larsen, J. D., Jasoni, R. L., Lucchesi, A. J., Batts, C. M., von Nagy, C., Coulombe, W. G., Schorran, D. E., Buck, P. E., Braswell, B. H., Coleman, J. S., Sherry, R. a., Wallace, L. L., Luo, Y., and Schimel, D. S.: Prolonged suppression of ecosystem carbon dioxide uptake after an anomalously warm year., Nature, 455, 383-6, 2008.

Asner, G. P., Kellner, J. R., Kennedy-Bowdoin, T., Knapp, D. E., Anderson, C., and Martin, R. E.: Forest Canopy Gap Distributions in the Southern Peruvian Amazon, PLOS ONE, 8, e60875, doi:10.1371/journal.pone.0060875, 2013.

Baldocchi, D., Falge, E., Gu, L., Olson, R., Hollinger, D., Running, S., Anthoni, P., Bernhofer, C., Davis, K., Evans, R., Fuentes, J., Goldstein, A., Katul, G., Law, B., Lee, X., Malhi, Y., Meyers, T., Munger, W., Oechel, W., Paw U, K. T., Pelegaard, K., Schmid, H. P., Valentini, R., Verma, S., Vesala, T., Wilson, K., and Wofsy, S.: FLUXNET: A new tool to study the temporal and spatial variability of ecosystem-scale carbon dioxide, water vapor, and energy flux densities, Bull. Am. Meteorol. Soc., 82, 2415-2434, 2001.

Barriopedro, D., Fischer, E. M., Luterbacher, J., Trigo, R. M., and García-Herrera, R.: The hot summer of 2010: redrawing the temperature record map of Europe., Science, 332, 220-4, 2011.

Beer, C., Reichstein, M., Tomelleri, E., Ciais, P., Jung, M., Carvalhais, N., Rödenbeck, C., Arain, M. A., Baldocchi, D., Bonan, G. B., Bondeau, A., Cescatti, A., Lasslop, G., Lindroth, A., Lomas, M., Luyssaert, S., Margolis, H., Oleson, K. W., Roupsard, O., Veenendaal, E., Viovy, N., Williams, C., Woodward, F. I., and 
Papale, D.: Terrestrial gross carbon dioxide uptake: global distribution and covariation with climate., Science, 329, 834-838, 2010.

Bigler, C., Gavin, D. G., Gunning, C., and Veblen, T. T.: Drought induces lagged tree mortality in a subalpine forest in the Rocky Mountains, Oikos, 116, 1983-1994, 2007.

Bollobas, B. and Riordan, O.: Percolation, Cambridge University Press, 2006.

Bondeau, A., Smith, P. C., Zaehle, S., Schaphoff, S., Lucht, W., Cramer, W., Gerten, D., Lotze-Campen, H., Müller, C., Reichstein, M., and Smith, B.: Modelling the role of agriculture for the 20th century global terrestrial carbon balance, Glob. Change Biol., 13, 679-706, 2007.

Bréda, N., Huc, R., Granier, A., and Dreyer, E.: Temperate forest trees and stands under severe drought: a review of ecophysiological responses, adaptation processes and long-term consequences, Ann. Forest Sci., 63, 625-644, 2006.

Chen, S., Lin, G., Huang, J., and Jenerette, G. D.: Dependence of carbon sequestration on the differential responses of ecosystem photosynthesis and respiration to rain pulses in a semiarid steppe, Glob. Change Biol., 15, 2450-2461, 2009.

Ciais, P., Reichstein, M., Viovy, N., Granier, A., Ogée, J., Allard, V., Aubinet, M., Buchmann, N., Bernhofer, C., Carrara, A., Chevallier, F., De Noblet, N., Friend, a. D., Friedlingstein, P., Gr"unwald, T., Heinesch, B., Keronen, P., Knohl, A., Krinner, G., Loustau, D., Manca, G., Matteucci, G., Miglietta, F., Ourcival, J. M., Papale, D., Pilegaard, K., Rambal, S., Seufert, G., Soussana, J. F., Sanz, M. J., Schulze, E. D., Vesala, T., and Valentini, R.: Europe-wide reduction in primary productivity caused by the heat and drought in 2003., Nature, 437, 529-33, 2005.

Clauset, A., Shalizi, C. R., and Newman, M. E. J.: Power-law distributions in empirical data, SIAM Review, 51, 661-703, 2009.

Coles, S.: An Introduction to Statistical Modeling of Extreme Values, Springer, London, 2001.

Coumou, D. and Rahmstorf, S.: A decade of weather extremes, Nat. Clim. Change, 2, 491-496, 2012.

Dee, D., Uppala, S., Simmons, A., Berrisford, P., Poli, P., Kobayashi, S., Andrae, U., Balmaseda, M., Balsamo, G., Bauer, P., Bechtold, P., Beljaars, A. C. M., van de Berg, L., Bidlot, J., Bormann, N., Delsol, C., Dragani, R., Fuentes, M., Geer, A. J., Haimberger, L., Healy, S. B., Hersbach, H., Hólm, E. V., Isaksen, L., Kållberg, P., Köhler, M., Matricardi, M., McNally, A. P., Monge-Sanz, B. M., Morcrette, J.-J., Park, B.-K., Peubey, C., de Rosnay, P., Tavolato, C., Thépaut, J.-N., and Vitart, F.: The ERA-Interim reanalysis: Configuration and performance of the data assimilation system, Q. J. Roy. Meteorol. Soc., 137, 553597,2011

Dong, X., Xi, B., Kennedy, A., Feng, Z., Entin, J. K., Houser, P. R., Schiffer, R. A., L'Ecuyer, T., Olson, W. S., Hsu, K.-1., Liu, W. T., Lin, B., Deng, Y., and Jiang, T.: Investigation of the 2006 drought and 2007 flood extremes at the Southern Great Plains through an integrative analysis of observations, J. Geophys. Res. Atmos., (1984-2012), 116, D03204, doi:10.1029/2010JD014776, 2011.

Farquhar, G., Caemmerer, S., and Berry, J.: A biochemical model of photosynthetic $\mathrm{CO}_{2}$ assimilation in leaves of $\mathrm{C}_{3}$ species, Planta, 149, 78-90, 1980.

Field, R. D., van der Werf, G. R., and Shen, S. S. P.: Human amplification of drought-induced biomass burning in Indonesia since 1960, Nat. Geosci., 2, 185-188, 2009.
Fisher, J. I., Hurtt, G. C., Thomas, R. Q., and Chambers, J. Q.: Clustered disturbances lead to bias in large-scale estimates based on forest sample plots., Ecol. Lett., 11, 554-63, doi:10.1111/j.14610248.2008.01169.x, 2008.

Friend, A. D. and Kiang, N. Y.: Land surface model development for the GISS GCM: Effects of improved canopy physiology on simulated climate, J. Climate, 18, 2883-2902, 2005.

Galvin, K. A., Boone, R. B., Smith, N. M., and Lynn, S. J.: Impacts of climate variability on East African pastoralists: Linking social science and remote sensing, Clim. Res., 19, 161-172, 2001.

Gerten, D., Schaphoff, S., Haberlandt, U., Lucht, W., and Sitch, S.: Terrestrial vegetation and water balance - hydrological evaluation of a dynamic global vegetation model, J. Hydrol., 286, 249270, 2004.

Ghil, M., Yiou, P., Hallegatte, S., Malamud, B. D., Naveau, P., Soloviev, a., Friederichs, P., Keilis-Borok, V., Kondrashov, D., Kossobokov, V., Mestre, O., Nicolis, C., Rust, H. W., Shebalin, P., Vrac, M., Witt, a., and Zaliapin, I.: Extreme events: dynamics, statistics and prediction, Non. Proc. Geophys., 18, 295-350, 2011.

Giglio, L., Randerson, J. T., van der Werf, G. R., Kasibhatla, P. S., Collatz, G. J., Morton, D. C., and DeFries, R. S.: Assessing variability and long-term trends in burned area by merging multiple satellite fire products, Biogeosciences, 7, 1171-1186, doi:10.5194/bg-7-1171-2010, 2010.

Gloor, M., Phillips, O. L., Lloyd, J. J., Lewis, S. L., Malhi, Y., Baker, T. R., López-Gonzalez, G., Peacock, J., Almeida, S., de OLIVEIRA, a. C. A., Alvarez, E., Amaral, I., Arroyo, L., Aymard, G., Banki, O., Blanc, L., Bonal, D., Brando, P., Chao, K.-J., Chave, J., Dávila, N., Erwin, T., Silva, J., Di FIORE, a., Feldpausch, T. R., Freitas, a., Herrera, R., Higuchi, N., Honorio, E., Jiménez, E., Killeen, T., Laurance, W., Mendoza, C., Monteagudo, a., Andrade, a., Neill, D., Nepstad, D., Vargas, P. N. n., Peñuela, M. C., Cruz, a. P. n., Prieto, a., Pitman, N., Quesada, C., Salomão, R., Silveira, M., Schwarz, M., Stropp, J., Ramírez, F., Ramírez, H., Rudas, a., ter STEEGE, H., Silva, N., Torres, a., Terborgh, J., Vásquez, R., and van der HEIJDEN, G.: Does the disturbance hypothesis explain the biomass increase in basin-wide Amazon forest plot data?, Glob. Change Biol., 15, 2418-2430, 2009.

Gumbel, E.: Statistics of extremes, Dover Publications, 2004.

Haxeltine, A. and Prentice, I.: A general model for the light-use efficiency of primary production, Funct. Ecol., 10, 551-561, 1996

Huete, A., Didan, K., Miura, T., Rodriguez, E., Gao, X., and Ferreira, L.: Overview of the radiometric and biophysical performance of the MODIS vegetation indices, Remote Sens. Environ., 83, 195-213, 2002.

Huxman, T. E., Snyder, K. A., Tissue, D., Leffler, A. J., Ogle, K., Pockman, W. T., Sandquist, D. R., Potts, D. L., and Schwinning, S.: Precipitation pulses and carbon fluxes in semiarid and arid ecosystems, Oecologia, 141, 254-268, 2004.

IPCC: Managing the Risks of Extreme Events and Disasters to Advance Climate Change Adaptation, A Special Report of Working Groups I and II of the Intergovernmental Panel on Climate Change, Cambridge University Press, Cambridge, UK, and New York, NY, USA, edited by: Field, C. B., Barros, V., Stocker, T. F., Qin, D., Dokken, D. J., Ebi, K. L., Mastrandrea, M. D., Mach, K. J., Plattner, G.-K., Allen, S. K., Tignor, M., Midgley, P. M.,, 2012. 
Irland, L. C.: Ice storms and forest impacts., The Science of the total environment, 262, 231-42, 2000.

Jentsch, A. and Beierkuhnlein, C.: Research frontiers in climate change: effects of extreme meteorological events on ecosystems, Compt. Rend. Geosci., 340, 621-628, 2008.

Jung, M., Reichstein, M., Margolis, H., Cescatti, A., Richardson, A., Arain, M., Arneth, A., Bernhofer, C., Bonal, D., Chen, J., Gianelle, D., Gobron, N., Kiely, G., Kutsch, W., Lasslop, G., E., L. B., Lindroth, A., Merbold, L., Montagnani, L., Moors, E. J., Papale, D., Sottocornola, M., Vaccari, F., and Williams, C.: Global patterns of land-atmosphere fluxes of carbon dioxide, latent heat, and sensible heat derived from eddy covariance, satellite, and meteorological observations, J. Geophys. Res, 116, G00J07, doi:10.1029/2010JG001566, 2011.

Keenan, T., Baker, I., Barr, A., Ciais, P., Davis, K., Dietze, M., Dragoni, D., Gough, C. M., Grant, R., Hollinger, D., Hufkens, K., Poulter, B., McCaughey, H., Raczka, B., Ryu, Y., Schaefer, K., Tian, H., Verbeeck, H., Zhao, M., and Richardson, A. D.: Terrestrial biosphere model performance for inter-annual variability of land-atmosphere $\mathrm{CO}_{2}$ exchange, Glob. Change Biol., 18, 19711987, 2012.

Kéfi, S., Rietkerk, M., Alados, C. L., Pueyo, Y., Papanastasis, V. P., ElAich, A., and De Ruiter, P. C.: Spatial vegetation patterns and imminent desertification in Mediterranean arid ecosystems, Nature, 449, 213-217, 2007.

Kellner, J. R. and Asner, G. P.: Convergent structural responses of tropical forests to diverse disturbance regimes., Ecol. Lett., 12, 887-97, 2009.

Körner, C.: Atmospheric science. Slow in, rapid out-carbon flux studies and Kyoto targets., Science, 300, 1242-3, 2003.

Krinner, G., Viovy, N., de Noblet-Ducoudré, N., Ogée, J., Polcher, J., Friedlingstein, P., Ciais, P., Sitch, S., and Prentice, I. C.: A dynamic global vegetation model for studies of the coupled atmosphere-biosphere system, Global Biogeochemical Cycles, 19, GB1015, doi:10.1029/2003GB002199, 2005.

Kurz, W. a., Dymond, C. C., Stinson, G., Rampley, G. J., Neilson, E. T., Carroll, a. L., Ebata, T., and Safranyik, L.: Mountain pine beetle and forest carbon feedback to climate change., Nature, 452, 987-90, 2008.

Leblanc, M. J., Tregoning, P., Ramillien, G., Tweed, S. O., and Fakes, A.: Basin-scale, integrated observations of the early $21 \mathrm{st}$ century multiyear drought in southeast Australia, Wat. Resour. Res., 45, W04408, doi:10.1029/2008WR007333, 2009.

Leonard, M., Westra, S., Phatak, A., Lambert, M., van den Hurk, B., McInnes, K., Risbey, J., Schuster, S., Jakob, D., and StaffordSmith, M.: A compound event framework for understanding extreme impacts, Wiley Interdisciplinary Reviews, Clim. Change, 2013

Lewis, S. L., Brando, P. M., Phillips, O. L., van der Heijden, G. M. F., and Nepstad, D.: The 2010 Amazon drought., Science, 331, 554, 2011.

Liu, Y., Liu, R., and Chen, J. M.: Retrospective retrieval of longterm consistent global leaf area index (1981-2011) from combined AVHRR and MODIS data, J. Geophys. Res. Biogeo., (2005-2012), 117, G04003, doi:10.1029/2012JG002084, 2012.

Lloyd-Hughes, B.: A spatio-temporal structure-based approach to drought characterisation, Int. J. Climat., 32, 406-418, 2012.
Marquet, P. A., Navarrete, S. A., and Castilla, J. C.: Scaling population density to body size in rocky intertidal communities., Science, 250, 1125-1127, 1990.

Minetti, J. L., Vargas, W. M., Poblete, A., Acuña, L., and Casagrande, G.: Non-linear trends and low frequency oscillations in annual precipitation over Argentina and Chile, 1931-1999, Atmósfera, 16, 119-135, 2009.

Morse, D., Lawton, J., Dodson, M., and Williamson, M.: Fractal dimension of vegetation and the distribution of arthropod body lengths, Nature, 314, 731-733, 1985.

Mueller, B. and Seneviratne, S. I.: Hot days induced by precipitation deficits at the global scale., P. Natl. Acad. Sci. USA, 109, 12398 403, 2012.

Mueller, B., Hirschi, M., Jimenez, C., Ciais, P., Dirmeyer, P. A., Dolman, A. J., Fisher, J. B. Jung, M., Ludwig, F., Maignan, F., Miralles, D. G., McCabe, M. F., Reichstein, M., Sheffield, J., Wang, K., Wood, E. F., Zhang, Y., and Seneviratne, S. I.: Benchmark products for land evapotranspiration: LandFlux-EVAL multi-dataset synthesis, Hydrol. Earth Syst. Sci., 17, 3707-3720, 2013, http://www.hydrol-earth-syst-sci.net/17/3707/2013/.

Myneni, R. B., Los, S. O., and Tucker, C. J.: Satellite-based identification of linked vegetation index and sea surface temperature Anomaly areas from 1982-1990 for Africa, Australia and South America, Geophys. Res. Lett., 23, 729-732, 1996.

Namias, J.: Spring and summer 1988 drought over the contiguous United States-Causes and prediction, J. Climate, 4, 54-65, 1991.

Negrón-Juárez, R. and Chambers, J.: Widespread Amazon forest tree mortality from a single cross-basin squall line event, Geophys. Res., 37, 1-5, 2010.

Newman, M. E. J.: Power laws, Pareto distributions and Zipf's law, Contemporary Physics, 46, 323-351, 2005.

Page, S. E., Siegert, F., Rieley, J. O., Boehm, H.-D. V., Jaya, A., and Limin, S.: The amount of carbon released from peat and forest fires in Indonesia during 1997, Nature, 420, 61-65, 2002.

Pascual, M. and Guichard, F.: Criticality and disturbance in spatial ecological systems., Trends in ecology \& evolution, 20, 88-95, 2005.

Phillips, O., Aragão, L., Lewis, S., and Fisher, J.: Drought sensitivity of the Amazon rainforest, Science, 323, 1344-1347, 2009.

Piao, S., Sitch, S., Ciais, P., Friedlingstein, P., Peylin, P., Wang, X., Ahlström, A., Anav, A., Canadell, J. G., Cong, N., Huntingford, C., Jung, M., Levis, S., Levy, P. E., Li, J., Lin, X., Lomas, M. R., Lu, M., Luo, Y., Ma, Y., Myneni, R. B., Poulter, B., Sun, Z., Wang, T., Viovy, N., Zaehle, S., and Zeng, N.: Evaluation of terrestrial carbon cycle models for their response to climate variability and to $\mathrm{CO}_{2}$ trends, Glob. Change Biol., 19, 2117-32, 2013.

Prentice, C. I., Sykes, M. T., and Cramer, W.: A simulation model for the transient effects of climate change on forest landscapes, Ecol. Modell., 65, 51-70, 1993.

Pueyo, S., de Alencastro Graça, P. M. L., Barbosa, R. I., Cots, R., Cardona, E., and Fearnside, P. M.: Testing for criticality in ecosystem dynamics: the case of Amazonian rainforest and savanna fire., Ecol. Lett., 13, 793-802, 2010.

Rao, V. B., Hada, K., and Herdies, D. L.: On the severe drought of 1993 in north-east Brazil, Int. J. Climatol., 15, 697-704, 1995.

Reichstein, M., Ciais, P., Papale, D., Valentini, R., Running, S., Viovy, N., Cramer, W., Granier, a., Ogée, J., Allard, V., Aubi- 
net, M., Bernhofer, C., Buchmann, N., Carrara, a., Grünwald, T., Heimann, M., Heinesch, B., Knohl, a., Kutsch, W., Loustau, D., Manca, G., Matteucci, G., Miglietta, F., Ourcival, J., Pilegaard, K., Pumpanen, J., Rambal, S., Schaphoff, S., Seufert, G., Soussana, J.-F., Sanz, M.-J., Vesala, T., and Zhao, M.: Reduction of ecosystem productivity and respiration during the European summer 2003 climate anomaly: a joint flux tower, remote sensing and modelling analysis, Glob. Change Biol., 13, 634-651, 2007.

Reichstein, M., Bahn, M., Ciais, P., Mahecha, M. D., Seneviratne, S. I., Zscheischler, J., Beer, C., Buchmann, N., Frank, D., Papale, D., Rammig, A., Smith, P., Thonicke, K., van der Velde, M., Vicca, S., Walz, A., and Wattenbach, M.: Climate extremes and the carbon cycle, Nature, 500, 287-295, 2013.

Rojas, O., Vrieling, A., and Rembold, F.: Assessing drought probability for agricultural areas in Africa with coarse resolution remote sensing imagery, Remote Sens. Environ., 115, 343-352, 2011.

Rouault, M. and Richard, Y.: Intensity and spatial extension of drought in South Africa at different time scales, Water SA, 29, 489-500, 2003.

Running, S. W., Thornton, P. E., Nemani, R., and Glassy, J. M.: Global terrestrial gross and net primary productivity from the Earth Observing System, Meth. Ecosyst. Sci., 44-57, 2000.

Running, S. W., Nemani, R. R., Heinsch, F. A., Zhao, M., Reeves, M., and Hashimoto, H.: A continuous satellite-derived measure of global terrestrial primary production, Bioscience, 54, 547560, 2004.

Seneviratne, S. I., Nicholls, N., Easterling, D., Goodess, C., Kanae, S., Kossin, J., Luo, Y., Marengo, J., McInnes, K., Rahimi, M., Reichstein, M., Sorteberg, A., Vera, C., and Zhang, X.: Changes in climate extremes and their impacts on the natural physical environment, in: Managing the Risks of Extreme Events and Disasters to Advance Climate Change Adaptation (IPCC SREX Report), edited by: Field, C., Barros, V., Stocker, T., Qin, D., Dokken, D., Ebi, K., Mastrandrea, M., Mach, K., Plattner, G.K., Allen, S., Tignor, M., and Midgley, P., 109-230, Cambridge University Press, 2012.

Sitch, S., Smith, B., Prentice, I. C., Arneth, a., Bondeau, a., Cramer, W., Kaplan, J. O., Levis, S., Lucht, W., Sykes, M. T., Thonicke, K., and Venevsky, S.: Evaluation of ecosystem dynamics, plant geography and terrestrial carbon cycling in the LPJ dynamic global vegetation model, Glob. Change Biol., 9, 161-185, 2003.

Siwkcki, R. and Ufnalski, K.: Review of oak stand decline with special reference to the role of drought in Poland, Europ. J. Forest Pathol., 28, 99-112, 1998.

Smith, M. D.: An ecological perspective on extreme climatic events: a synthetic definition and framework to guide future research, J. Ecol., 99, 656-663, 2011.
Sornette, D.: Critical Phenomena in Natural Sciences: Chaos, Fractals, Selforganization and Disorder, Springer Verlag, 2006.

Sun, Y., Gu, L., Dickinson, R. E., and Zhou, B.: Forest greenness after the massive 2008 Chinese ice storm: integrated effects of natural processes and human intervention, Environ. Res. Lett., 7, 035702, doi:10.1088/1748-9326/7/3/035702, 2012.

Thonicke, K., Spessa, A., Prentice, I. C., Harrison, S. P., Dong, L., and Carmona-Moreno, C.: The influence of vegetation, fire spread and fire behaviour on biomass burning and trace gas emissions: results from a process-based model, Biogeosciences, 7, 1991-2011, doi:10.5194/bg-7-1991-2010, 2010.

Touboul, J. and Destexhe, A.: Can power-law scaling and neuronal avalanches arise from stochastic dynamics?, PLoS One, 5, e8982, doi:10.1371/journal.pone.0008982, 2010.

Turcotte, D. L., Malamud, B. D., Guzzetti, F., and Reichenbach, P.: Self-organization, the cascade model, and natural hazards, P. Natl. Acad. Sci. USA, 99, 2530-2537, 2002.

Ummenhofer, C. C., England, M. H., McIntosh, P. C., Meyers, G. A., Pook, M. J., Risbey, J. S., Gupta, A. S., and Taschetto, A. S.: What causes southeast Australia's worst droughts?, Geophys. Res. Lett., 36, L04706, doi:10.1029/2008GL036801, 2009.

Varadhan, S. R. S.: Asymptotic probabilities and differential equations, Communications on Pure and Applied Mathematics, 19, 261-286, 1966.

Waple, A. and Lawrimore, J.: State of the climate in 2002, Bull. Am. Meteorol. Soc., 84, 800-800, 2003.

Westerling, a. L., Hidalgo, H. G., Cayan, D. R., and Swetnam, T. W.: Warming and earlier spring increase western U.S. forest wildfire activity., Science (New York, N.Y.), 313, 940-3, 2006.

Zaehle, S. and Friend, A. D.: Carbon and nitrogen cycle dynamics in the O-CN land surface model: 1 . Model description, sitescale evaluation, and sensitivity to parameter estimates, Glob. Biogeochem. Cy., 24, GB1005, 2010. blackboxPlease add doi

Zeng, H., Chambers, J. Q., Negrón-Juárez, R. I., Hurtt, G. C., Baker, D. B., and Powell, M. D.: Impacts of tropical cyclones on U.S. forest tree mortality and carbon flux from 1851 to 2000., P. Natl. Acad. Sci. USA, 106, 7888-92, 2009.

Zhao, M. and Running, S. W.: Drought-induced reduction in global terrestrial net primary production from 2000 through 2009., Science, 329, 940-3, 2010.

Zscheischler, J., Mahecha, M. D., Harmeling, S., and Reichstein, M.: Detection and attribution of large spatiotemporal extreme events in Earth observation data, Ecol. Info., 15, 66-73, 2013.

Zscheischler, J., Mahecha, M. D., von Buttlar, J., Harmeling, S., Jung, M., Rammig, A., Randerson, J., Schölkopf, B., Seneviratne, S. I., Tomelleri, E., Zaehle, S., and Reichstein, M.: A few extreme events dominate global interannual variability in gross primary production, Environmental Research Letters, 9, 035001, doi:10.1088/1748-9326/9/3/035001, 2014. 